\title{
The Correlation between EFL Students' Anxiety and Their English Writing Skills
}

\author{
Wira Kafryawan* \\ IAIN Fattahul Muluk Papua, 99224, Indonesia \\ wira@iainfmpapua.ac.id \\ *corresponding author
}

Andi Miftahul Maulidil Mursyid

IAIN Fattahul Muluk Papua, 99224, Indonesia

andi@iainfmpapua.ac.id

Rahmawansyah Sahib

IAIN Fattahul Muluk Papua, 99224, Indonesia

rahmawansyahiainpapua@gmail.com

Heni Purwati

IAIN Fattahul Muluk Papua, 99224, Indonesia

heni@iainfmpapua.ac.id

\section{Article History \\ Received: 2 February 2021 \\ Reviewed: 1 March 2021 \\ Accepted: 22 March 2021 \\ Published: 27 April 2021 \\ Highlights \\ There is a significant correlation between EFL students' anxiety and their English writing skills.}

\begin{abstract}
Anxiety in writing contains tension, nervousness, worry, and a wide variety of other negative feelings when someone is given a task to write in a certain situation. The objective of this study is to figure out whether or not there is a significant correlation between EFL students' anxiety and their English writing skills. The subject of the study is the fourth semester of EFL students in the State Islamic Institute of Fattahul Muluk Papua. The study focused on a correlational method of two quantifiable variables involving anxiety and English writing skills. Two instruments are used in this study including Foreign Language Writing Anxiety Inventory (FLWAI) developed by Cheng and the writing test developed by Heaton. The samples are 40 EFL students as the respondents and the data were calculated by Pearson product-moment. The findings reveal that there is a significant correlation between EFL students' anxiety and their English writing skills at a high level. It means that the lower anxiety belongs to EFL students, the better they write in English. Moreover, cognitive anxiety is the most influential anxiety on EFL students' English writing skills. Then, it is followed by somatic anxiety, and avoidance behavior is also fairly influential.
\end{abstract}

Keywords: Anxiety, Writing Skills, EFL Students

\section{Introduction}

There is no doubt that English writing skills are as essential as other English language skills. Among the other language skills, writing skills, which stand for the productive skills, are the focus of attention of this study. The ability to write is frequently demanded on many occasions in our circumstances. Learners want to write due to the fact that they want to express their feelings, ideas, and thoughts, and their writing wants to be read by others. According to 
(Rao, 2007), writing skills encourage EFL students both to think and stimulate them to produce and recap new ideas. It also reinforces how to think during learning. Furthermore, writing skills provide EFL students with a means to convey their feelings, achievements, dreams, and opinions. It also fills the gap and connects them across borders and from diverse backgrounds. On the other hand, writing is considered the most interesting language skills for both first and foreign language students to master (Umar \& Rathakrishnan, 2012).

When we have a look around the quality of learning focused on writing ability in Indonesia, the habit of writing in the EFL classroom is still below the standard of measurement, it can be proven by the number of EFL students' writing results every year. Moreover, most of the EFL students face some difficulties to develop their writing ability. It can be assumed that the difficulties in writing are caused by many factors. Some of them are from the internal factors themselves, such as interests, curiosity, emotions, self-esteem, aptitude, and anxiety to write. Anxiety is regarded as the most essential factor which affects EFL students' writing skills.

Anxiety can be said that the state of feeling nervous or worried that something bad is going to happen (Santrock, 2011). Based on the previous observation, some EFL students' difficulties in writing are obviously influenced by their anxiety. Anxiety in writing contains tension, nervousness, worry, and a wide variety of other negative feelings when someone is given a task to write in a certain situation. According to Krashen (1982), students with low anxiety seem to be conducive to second language acquisition. Students who have lower anxiety tend to be more skilled in acquiring language than the higher ones. In addition, Hassan (2001) also stated that low anxious students perform quality compositions better than high anxious ones. It is understood that reading and listening are receptive skills and writing and speaking are productive skills. Chow et al. (2018) in their study found that there is a substantial correlation between foreign language Chinese undergraduate students' anxiety and their reading and listening skills. It is proved that some skills, especially receptive skills, have a correlation to anxiety. Based on the previous assumption, it is hypothesized that students with a low level of anxiety will achieve better skills than those who have a high level of anxiety. The emerging problem is there is no authentic proof from the previous hypothesis which has been stated. It is essential to prove the influence of anxiety towards EFL students' writing skills with the purpose of giving contributions and new findings related to the teaching and learning of EFL students. Therefore, the objective of the study is to figure out whether or not there is a significant correlation between EFL students' anxiety and their English writing skills.

Some related theories presented whether to support and develop or deny the findings later. There are three kinds of anxiety offered by psychologists, namely trait anxiety as a feature of personality, state anxiety as a reaction to a particular stimulus that induces anxiety, such as major examinations, and situation-specific anxiety as anxiety induced in specific situations, and it is regarded as the primary type of language anxiety (Horwitz, 2001). Several factors affect the writing of a foreign language by EFL students. They involve a lack of foreign language writing practice, fear of having a negative evaluation, poor mastery of writing technique, and lack of knowledge in the language. Additionally, getting plenty of linguistic language issues such as vocabulary, grammar, and diction. The stress to work perfectly on foreign language essays, lack of confidence, time pressure also become the key factors to 
writing anxiety of EFL students. (Younas et al., 2014). According to Salikin (2019) in his study, EFL students experienced an average level of English writing anxiety as a preference, particularly cognitive anxiety. In terms of writing English compositions, female students appear to have slightly higher levels of anxiety than male ones related to gender. The study further indicates that both male and female students were pressured by anxiety due to a lack of linguistic competence. Furthermore, creating different sections of a research paper provoked different stages of anxiety due to the variations in the rhetorical purposes and discourse structures of particular sections (Ho, 2015). Writing anxiety is a common issue influencing the writing skills of EFL students. The results found that if it is compared to those with low levels of cognitive, somatic, and avoidance anxiety, students with higher cognitive, somatic, and avoidance anxiety had a greater interest in writing activities. This affects their readiness to do writing tasks in English. This study is also intended to encourage classroom activities so that students can engage in their writing assignments more efficiently (Rahim et al., 2016). Cheng (2002) in his writing anxiety study suggests that encouraging the positive and practical understanding of students' writing skills is as necessary as improving the writing skills of the student. The last, he employed factor analysis of the Second Language Writing Anxiety Inventory (SLWAI) that contains three subscales: 1) Somatic Anxiety, 2) Cognitive Anxiety, and 3) Avoidance Behavior. The results suggest that both the total scale and the individual subscales of the SLWAI have good reliability and adequate validity (Cheng, 2004).

\section{Method}

The study focused on a correlational method involving two quantifiable variables. The first quantifiable variable is EFL students' anxiety and the second quantifiable variable is EFL students' writing skills. The subject of the study is the fourth semester of EFL students in the State Islamic Institute of Fattahul Muluk Papua. When all population members are used as subjects, Saturated Sampling was used as the method of determining the sample. The study then applied 40 EFL students as the respondents.

Two instruments were used in this study involving Foreign Language Writing Anxiety Inventory (FLWAI) developed by Cheng and the writing test developed by Heaton. The FLWAI was conducted in order to collect quantifiable data about the EFL students' level of anxiety in writing English as a foreign language. The FLWAI is a 5-point Likert-scale ranging from 1 indicating 'strongly disagree' to 5 indicating 'strongly agree.' FLWAI has three subcategories: cognitive, somatic, and avoidance behavior (Cheng, 2004). Besides, the questionnaires were modified by adding the Anxiety Control Questionnaire (ACS) (Weems et al., 2003). The writing test was conducted in order to collect quantifiable data about EFL students' writing skills. Writing assessment has five subcategories: content, organization, vocabulary, language use, and mechanics (Heaton, 1975). Interrater reliability was applied in a writing test involving $5 \mathrm{EFL}$ lecturers to assess data more objectively.

Both alternative hypothesis $(\mathrm{H} \alpha)$ and Null Hypothesis (Ho) were proposed in this study. The hypothesis of the study was formulated with consideration: $(\mathrm{H} \alpha)$ there is a correlation between EFL students' anxiety and their English writing skills, and (Ho) there is no correlation between EFL students' anxiety and their English writing skills. Besides, data analysis based on 
Kafryawan, Mursyid, Sahib, and Purwati. Tell: Teaching of English Language and Literature Vol. 9, No.1, April - 2021 Doi: http://dx.doi.org/10.30651/tell.v9i1.7372

Pearson Product Moment where the results within a certain range on EFL students' anxiety as the first variable were associated with the data in a particular range on EFL students' writing skills as the second variable was applied with the following formula:

$$
\frac{\sum X Y-\frac{\left(\sum X\right)\left(\sum Y\right)}{N}}{\sqrt{\left[\sum X^{2}-\frac{\left(\sum X\right)^{2}}{N}\right]\left[\sum Y^{2}-\frac{\left(\sum Y\right)^{2}}{N}\right]}}
$$

ro $\quad=$ correlational coefficient

$\mathrm{N}=$ the amount of respondents

$\mathrm{X} \quad=$ variable of EFL students' anxiety

$\mathrm{Y} \quad=$ variable of EFL students' writing skills

$\sum X \quad=$ the amount of anxiety value of EFL students

$\sum \mathrm{Y}=$ the amount of writing skills value of EFL students

$\sum X^{2}=$ the amount of square in the $\mathrm{X}$-variable

$\sum \mathrm{Y}^{2}=$ the amount of square in the $\mathrm{Y}$-variable

(Gay, 1996)

\section{Findings}

Table 1

Data Distribution of EFL Students' Anxiety and Their English Writing Skills

\begin{tabular}{cccccc}
\hline No & $\mathbf{X}$ & $\mathbf{Y}$ & $\mathbf{X}^{\mathbf{2}}$ & $\mathbf{Y}^{\mathbf{2}}$ & $\mathbf{X Y}$ \\
\hline 1 & 25 & 85 & 625 & 7225 & 2125 \\
\hline 2 & 20 & 85 & 400 & 7225 & 1700 \\
\hline 3 & 32 & 80 & 1024 & 6400 & 2560 \\
\hline 4 & 25 & 82 & 625 & 6724 & 2050 \\
\hline 5 & 20 & 90 & 400 & 8100 & 1800 \\
\hline 6 & 22 & 85 & 484 & 7225 & 1870 \\
\hline 7 & 20 & 88 & 400 & 7744 & 1760 \\
\hline 8 & 35 & 80 & 1225 & 6400 & 2800 \\
\hline 9 & 30 & 88 & 900 & 7744 & 2640 \\
\hline 10 & 35 & 79 & 1225 & 6241 & 2765 \\
\hline 11 & 25 & 85 & 625 & 7225 & 2125 \\
\hline 12 & 25 & 90 & 625 & 8100 & 2250 \\
\hline 13 & 27 & 89 & 729 & 7921 & 2403 \\
\hline 14 & 30 & 85 & 900 & 7225 & 2550 \\
\hline 15 & 35 & 72 & 1225 & 5184 & 2520 \\
\hline 16 & 36 & 70 & 1296 & 4900 & 2520 \\
\hline 17 & 20 & 90 & 400 & 8100 & 1800 \\
\hline 18 & 20 & 88 & 400 & 7744 & 1760 \\
\hline 19 & 22 & 85 & 484 & 7225 & 1870 \\
\hline 20 & 21 & 87 & 441 & 7569 & 1827 \\
\hline 21 & 25 & 85 & 625 & 7225 & 2125 \\
\hline 22 & 20 & 89 & 400 & 7921 & 1780 \\
\hline 23 & 33 & 75 & 1089 & 5625 & 2475 \\
\hline & & & & &
\end{tabular}


Kafryawan, Mursyid, Sahib, and Purwati. Tell: Teaching of English Language and Literature Vol. 9, No.1, April - 2021 Doi: http://dx.doi.org/10.30651/tell.v9i1.7372

\begin{tabular}{cccccc}
\hline 24 & 35 & 73 & 1225 & 5329 & 2555 \\
\hline 25 & 30 & 80 & 900 & 6400 & 2400 \\
\hline 26 & 38 & 70 & 1444 & 4900 & 2660 \\
\hline 27 & 25 & 86 & 625 & 7396 & 2150 \\
\hline 28 & 21 & 90 & 441 & 8100 & 1890 \\
\hline 29 & 20 & 88 & 400 & 7744 & 1760 \\
\hline 30 & 25 & 80 & 625 & 6400 & 2000 \\
\hline 31 & 20 & 90 & 400 & 8100 & 1800 \\
\hline 32 & 21 & 90 & 441 & 8100 & 1890 \\
\hline 33 & 25 & 80 & 625 & 6400 & 2000 \\
\hline 34 & 38 & 70 & 1444 & 4900 & 2660 \\
\hline 35 & 24 & 82 & 576 & 6724 & 1968 \\
\hline 36 & 25 & 83 & 625 & 6889 & 2075 \\
\hline 37 & 20 & 92 & 400 & 8464 & 1840 \\
\hline 38 & 35 & 71 & 1225 & 5041 & 2485 \\
\hline 39 & 30 & 80 & 900 & 6400 & 2400 \\
\hline 40 & 28 & 82 & 784 & 6724 & 2296 \\
\hline $\mathbf{N}$ & $\sum \mathbf{X}$ & $\sum \mathbf{Y}$ & $\sum \mathbf{X}^{\mathbf{2}}$ & $\sum \mathbf{Y}^{\mathbf{2}}$ & $\sum \mathbf{X Y}$ \\
\hline $\mathbf{4 0}$ & $\mathbf{1 0 6 3}$ & $\mathbf{3 3 1 9}$ & $\mathbf{2 9 6 2 7}$ & $\mathbf{2 7 7 0 0 3}$ & $\mathbf{8 6 9 0 4}$ \\
\hline & & & & &
\end{tabular}

Table 1 above showed the findings of both quantifiable variables. Based on the raw data of EFL students' anxiety represented by variable $X$ were correlated to EFL students' writing skills represented by variable $\mathrm{Y}$. The final scores in Table 1 showed that $\mathrm{N}(40), \Sigma X(1063), \Sigma \mathrm{Y}$ (3319), $\Sigma X^{2}$ (29627), $\Sigma Y^{2}$ (277003), $\Sigma X Y$ (86904). Then, overall data calculated by using Pearson Product Moment were found in the following result. Therefore, it was found the final result that the correlation coefficient (ro) is 0.87 .

Table 2

Data Interpretation of EFL Students' Anxiety and Their English Writing Skills

\begin{tabular}{|c|c|}
\hline 'r' value & Interpretation \\
\hline 0.00 until 0.20 & Considered as No Correlation \\
\hline 0.20 until 0.40 & Low Correlation \\
\hline 0.40 until 0.70 & Medium Correlation \\
\hline 0.70 until 0.90 & High Correlation \\
\hline 0.90 until 1.00 & Very High/ Perfect Correlation \\
\hline
\end{tabular}

(Sudijono, 2005)

There are several levels of significance interpreted from no correlation to perfect correlation. Based on the interpretation of Table 2 above, the correlational coefficient $(0.87)$ lies on the interval of 0.70 until 0.90 , which represents that the correlation refers to high correlation. In other words, there is a significant correlation in level of a high or strong correlation between EFL students' anxiety and their English writing skills. The validity of data is tested by a degree of freedom and significant critical value by the following formula: $(\mathrm{N}-$ $\mathrm{nr}=\mathrm{df}, 40-2=38$ ) where $\mathrm{df}$ is Degree of Freedom, $\mathrm{N}$ is a number of respondents, and $\mathrm{nr}$ is a number of variables. The value of ro is 0.87 ; $\mathrm{df}$ is 38 . Furthermore, the data were measured with the $r$ table of tabulation at the degree of significance 5\% (0.3044) and 1\% (0.3932) for data validation. This calculation found that the correlation between EFL students' anxiety and 
their writing skills lies on high level correlation based on the hypothesis (ro: $\mathrm{rt}=0.8700>$ 0.3044 for $5 \%$ significance; ro: $\mathrm{rt}=0.8700>0.3932$ for $1 \%$ significance). Based on the hypothesis, the null hypothesis (Ho) of the study is rejected, and an alternative hypothesis of the study $(\mathrm{H} \alpha)$ is accepted. In other words, there is a significant correlation between EFL students' anxiety and their English writing skills at a high level. It means that the lower anxiety belongs to EFL students, the better they write in English.

\section{Discussion}

Broad explanations elaborated based on the final result of the findings, anxiety as one of the internal psychological factors has a tremendous influence on EFL students' writing skills. It is very determinant towards EFL students' ability on writing. All of the writing elements are significantly affected by anxiety. Content of writing referring to substantive knowledge is highly influenced by anxiety, where it must hinder essential points to create good quality of writing. Organization of writing referring to clear ideas is highly influenced by anxiety, which means it can distract the clarity of writing when someone is writing. The vocabulary of writing referring to effective word choice and usage is fairly influenced by anxiety, where the more vocabularies you have, the more creativity of writing you produce. Therefore, the amount of word choices may decrease when distracted. Language use of writing referring to effective complex construction is highly influenced by anxiety that language use relates to semantic and pragmatic aspects. Mechanics of writing referring to the mastery of convention is fairly influenced by anxiety where construction of the writing will be less complex and structured. Related to three types of language writing anxiety: cognitive anxiety, somatic anxiety, and avoidance behavior have various influences on EFL students' writing skills.

Cognitive anxiety is a mental expression of anxiety or a specific thought mechanism (Cheng, 2004). Mental features of cognitive anxiety include panic attacks, irritability, restlessness, poor concentration, incoherence in speaking and writing, fear, and the inability to move (Larson, 2009). Moreover, High levels of anxiety lead to less attention on the task, difficulty with the successful use of working memory, more superficial processing and less indepth processing, and issues in the use of metacognitive regulation processes to regulate learning in terms of real cognitive functions when performing the task (Reynolds et al., 2003). Related to the findings, cognitive anxiety is a primary determinant towards EFL students' writing skills. Cognitive anxiety contributes to mental aspects, like a lot of negative expectations, a performance that impacts the mind and thoughts about the opinions of EFL students. In other words, Cognitive anxiety is associated with the behavior and mechanism of anxiety itself in their mind when facing challenging situations along with having a feeling of failure such as 'I'm never going to finish this writing' and self-insulting such as 'I write quite poorly.' Regarding the writing performance, this kind of anxiety influences the mentality of EFL students. They tend to be less confident in their writing ability, and it automatically decreases their both intrinsic motivation and self-efficacy to write. Anxiety is considered not only as a negative factor but also as a positive factor. It can be harmful to anxiety 'debilitative' and helpful anxiety 'facilitative' (Brown, 2000). Too much anxiety can be harming and hindering a students' performance, while a minimal amount of anxiety can support and 
encourage their performance (Salkind, 2008). Against the findings, some students in certain cases create their anxiety when doing something poorly to motivate themselves to try harder and study more. It is called defensive pessimist (Reynolds et al., 2003). Therefore, EFL teachers should particularly guide students to trigger their defensive pessimists of writing when anxiety belongs to them.

Somatic anxiety is a physical expression of anxiety, also called somatization (Cheng, 2004). Physical features of somatic anxiety include dizziness, faintness, sweating, tremor, the tension in the neck, stomach or chest pain, nausea, shortness of breath, diarrhea, increased urination, palpitations, hyperventilation, and insomnia (Larson, 2009). Related to the findings, somatic anxiety is a secondary determinant towards EFL students' writing skills. Somatic anxiety contributes to the physiological effect of the anxiety experienced by EFL students. It is expressed in a rising autonomous stimulus and unpleasantness, such as anxiety itself and tension. That is to say that somatic anxiety is related to the condition of EFL students' physics when they feel anxious, such as trembling, headaches, sweating, and crisis rate changes. Based on the relationship in writing performance, this kind of anxiety influences the physical of the EFL students. They cannot write fluently because of sweating or trembling. In other words, the performance of writing is halted by physical distractors.

Avoidance behavior is an attitude change expression when having been anxious (Cheng, 2004). Related to the previous findings, avoidance behavior is a tertiary determinant towards EFL students' writing skills. Avoidance behavior contributes to the characteristics of attitudes or behaviors when EFL students feel nervous, although it seldom occurs. For instance, when they have choices on which language to write, they obviously prefer to choose their first language. Fear of writing English language compositions may be why they suffer from avoidance behavior. Related to the writing performance, this kind of anxiety influences the behavior of EFL students. They tend to give up before trying to write. Negative behavior appears to avoid challenges.

Some problems why EFL students feel anxious when getting writing tasks were found in certain cases. First, there is a fear of teachers' negative comments (Younas et al., 2014). EFL students tend to be afraid of or even fearful of the teacher's critical comments to them. They feel afraid of being criticized by their teacher later when they are given writing tasks to finish. It is synchronized with their cognitive anxiety. (Ohata, 2005) reports that one of the component factors of language anxiety in L2 processes is fear of negative evaluation. That EFL students perform in the classroom. They frequently are worried about their compositions in a foreign language writing of being evaluated by the teachers or their peers. In certain situations, fear of other assessments can contribute to feelings of embarrassment that their writing compositions are criticized in front of other students. Due to the fear of getting a negative evaluation, EFL students are unconsciously required to write the compositions perfectly. Consequently, they are terrified by their peers ridiculing their compositions when they are not doing the task perfectly. Consequently, they are terrified by their peers ridiculing their compositions when they are not doing the task completely. Second, there is an insufficient writing practice (Younas et al., 2014). Most EFL students have less writing practice and techniques. It is because of laziness to write. It means that the habit of spending time doing nothing. Moreover, the 
influence of social media makes them lazy to write. Third, there are linguistic difficulties (Younas et al., 2014). Because of English as a foreign language, some EFL students have a problem with grammar, vocabulary, and diction. They need to master some aspects before they start to write. Fourth, there is a pressure of perfect writing and pressure of time (Younas et al., 2014). Some EFL students feel that they must complete their writing on time completely. It can trigger their anxiety intrinsically. It is also synchronized with their cognitive anxiety.

From my point of view, having various levels of anxiety related to writing ability is a normal condition. By approaching it as something that stays beyond their control, an EFL student may reduce the levels of tension and stress that surround writing an article. There are some strategies that prove successful in coping with EFL students dealing with their anxiety in writing. They can diminish the importance of writing 'I am just writing a thesis, no big deal.' This strategy works because it changes that the student's subconscious mind is obviously cheated. If someone has an anxiety-provoking task such as work on a dissertation or write on thesis, delete that entry of mind. Instead, someone may add this non-threatening task such as: write an email or writing a poem. Established targets, including certain section writing when getting a good score and then carry out a reward. Take a break and appreciate yourself with small rewards like buying a drink, inviting a friend, enjoying your favorite TV show, etc., keep your feeling and mind from being exhausted, and improvement of good behavior. The creative floodgates will be developed by trying freewriting and clustering. This strategy is useful to reduce writing anxiety and improve the ability and performance to write for EFL students.

As a teacher, we need to recognize more deeply characteristics of anxiety, whether it is trait anxiety or state anxiety. Trait anxiety is more permanent to be anxious, and state anxiety is experienced in response to a particular event or act (Brown, 2000). It is important for EFL teachers to diagnose whether EFL students' anxiety stands for more global traits or particular traits. Besides, parental guidance is useful to help when a student with special needs requires parents and other family members to make changes positively within themselves, to meet the needs of the new environment and, to cope with problems of anxiety (Ebersöhn \& Eloff, 2004). It is also essential for either parents or family members as a guide at home in recognizing the particular disorders to minimize the students' anxiety and encourage them to maximize their potency in writing ability.

\section{Conclusion}

Generally, it was found that there is a significant correlation between EFL students' anxiety and their English writing skills at IAIN Fattahul Muluk Papua, Faculty of Tarbiyah, English Education Study Program, where the correlation lies on high correlation. It means that the lower anxiety belongs to EFL students, the better ability they write in English. Moreover, cognitive anxiety is the most influential anxiety on EFL students' English writing skills. Then, it is followed by somatic anxiety, and avoidance behavior is also quite influential. Many further experiments are required to be broadly expanded and explained the anxiety of EFL students and their writing skills more specifically.

The pedagogical implications from the study involve writing anxiety among EFL students can be minimized by appreciating them and omitting the fear of exams, the level of writing 
Kafryawan, Mursyid, Sahib, and Purwati. Tell: Teaching of English Language and Literature Vol. 9, No.1, April - 2021 Doi: http://dx.doi.org/10.30651/tell.v9i1.7372

anxiety among EFL students can be minimized by sufficient writing practice and writing technique awareness, trying to settle EFL students' linguistic problems and increasing their selfconfidence will alleviate writing anxiety, a large number of writing tasks must be avoided, so EFL students can feel secure with their writing tasks to accomplish, writing anxiety can be minimized, and the students' writing ability can be gradually increased through positive reinforcement. Furthermore, it is the obligation that EFL teachers should lead them to decrease their writing mistakes and errors.

\section{References}

Brown, H. D. (2000). Principles of language learning and teaching (Vol. 4). Longman New York.

Cheng, Y. S. (2002). Factors associated with foreign language writing anxiety. Foreign Language Annals, 35(6), 647-656. https://doi.org/10.1111/j.1944-9720.2002.tb01903.x

Cheng, Y. S. (2004). A measure of second language writing anxiety: Scale development and preliminary validation. Journal of Second Language Writing, 13(4), 313-335. https://doi.org/10.1016/j.jslw.2004.07.001

Chow, B. W. Y., Chiu, H. T., \& Wong, S. W. L. (2018). Anxiety in reading and listening English as a foreign language in Chinese undergraduate students. Language Teaching Research, 22(6), 719738. https://doi.org/10.1177/1362168817702159

Ebersöhn, L., \& Eloff, I. (2004). Keys to educational psychology. Juta and Company Ltd.

Gay, L. R. (1996). Educational Research: Competencies for Analysis and Application (5th ed.). In New Jersey:Prentice-Hall.

Hassan, B. (2001). The Relationship of Writing Apprehension and Self-Esteem to the Writing Quality and Quantity of EFL University Students. Mansoura Faculty of Education Journal.

Heaton, J. B. (1975). Writing English language tests: A practical guide for teachers of English as a second or foreign language. Addison-Wesley Longman Limited.

Ho, M. (2015). Exploring Writing Anxiety and Self-Efficacy among EFL Graduate Students in Taiwan. Higher Education Studies, 6(1), 24-39. https://doi.org/10.5539/hes.v6n1p24

Horwitz, E. (2001). Language anxiety and achievement. Annual Review of Applied Linguistics, 21(2), 112-126. https://doi.org/10.1017/s0267190501000071

Krashen, S. (1982). Principles and practice in second language acquisition.

Larson, J. E. (2009). Educational psychology: Cognition and learning, individual differences and motivation. Nova Science Publishers, Incorporated.

Ohata, K. (2005). Potential Sources of Anxiety for Japanese Learners of English: Preliminary Case Interviews with Five Japanese College Students in the U.S. TESL-EJ, 9(3), 1-21.

Rahim, S. A., Jaganathan, P., Sepora, T., \& Mahadi, T. (2016). An Investigation on the Effects of Writing Anxiety on Readiness of Writing among Low Proficiency Undergraduates. International Journal of Language Education and Applied Linguistics (IJLEAL).

Rao, Z. (2007). Training in brainstorming and developing writing skills. ELT Journal, 61(2), 100-106. https://doi.org/10.1093/elt/ccm002

Reynolds, W. M., Miller, G. E., \& Weiner, I. B. (2003). Handbook of psychology.

Salikin, H. (2019). Factors affecting male and female Indonesian EFL students' writing anxiety. Indonesian Journal of Applied Linguistics, 9(2), 316-323. https://doi.org/10.17509/ijal.v9i2.20229

Salkind, N. J. (2008). Encyclopedia of educational psychology. SAGE publications.

Santrock, J. W. (2011). Educational Psychology 5th Edition. Educational Psychology.

Sudijono, A. (2005). Pengantar statistik pendidikan. PT Raja Grafindo Persada.

Umar, I. N., \& Rathakrishnan, M. (2012). The Effects of Online Teachers' Social Role and Learning Style on Students' Essay Writing Performance and Critical Thinking in a Wiki Environment.

Procedia - Social and Behavioral Sciences, 46, 5730-5735.

https://doi.org/10.1016/j.sbspro.2012.06.506 
Kafryawan, Mursyid, Sahib, and Purwati. Tell: Teaching of English Language and Literature Vol. 9, No.1, April - 2021 Doi: http://dx.doi.org/10.30651/tell.v9i1.7372

Weems, C. F., Silverman, W. K., Rapee, R. M., \& Pina, A. A. (2003). The role of control in childhood anxiety disorders. Cognitive Therapy and Research, 27(5), 557-568. https://doi.org/10.1023/A:1026307121386

Younas, M., Hamid, M., \& Farzeen, M. (2014). Exploring the Causes of Writing Anxiety : A Case of B . S . English Students. Language in India, 14(8), 197-208. 